\title{
The Accounting Education Gap in Brazil
}

\author{
Gilberto José Miranda \\ Federal University of Uberlândia, Uberlândia, Brazil \\ Silvia Pereira de Castro Casa Nova, Edgard Bruno Cornacchione Junior \\ University of São Paulo, São Paulo, Brazil
}

\begin{abstract}
Emerging countries face the challenge of training highly qualified people to support recent economic advances. To overcome this challenge, the qualification of university professors plays an important role. The aim of the present study is to examine the impact of the qualification of teachers on the performance of their students in Brazil, in a specific field of business education-accounting. Scholars focused on teaching methods point out two essential qualifications for an accounting faculty: academic qualification (Qac), which refers to the preparation to conduct research; and professional qualification (Qpr), characterized by the link with current professional practices. Based on the human capital theoretical framework, this study aims at investigating which variables of Qac and Qpr of accounting faculty in Brazil are related to student performance, as measured by the Brazilian nationwide postsecondary student evaluation system (ENADE). A questionnaire was administered to 218 institutions of higher education (IHE) with undergraduate accounting programs. Only 7\% of the faculty members hold a Ph.D. degree; $14 \%$ have relevant publications; and just 5\% have auditor credentials. Positive and significant correlation between academic qualification (Qac) and student performance was found. The results suggest that, to improve the quality of education in accounting in Brazil, more investment is necessary in the academic qualification of teachers.
\end{abstract}

Keywords: accounting education, faculty credentials, student performance, academic qualification, professional qualification, Brazil

\section{Introduction}

Emerging countries face the challenge of training highly qualified people to sustain their cycle of economic growth. This is particularly true of the so-called "BRICs", a term coined at the turn of this century by analysts at Goldman Sachs for Brazil, Russia, India, and China. Although these countries share a similar stage of economic development and the inherent challenges, studies warn of the fallacy of using the abbreviation to describe the four countries as part of a uniform bloc, without attention to the particularities of each one, both in the media and academia (Ardichvili et al., 2012). Therefore, studies focused on the specific aspects of each of these countries are important, to enable comprehension of each one and comparisons among them. This study

Gilberto José Miranda, Doctor in Accounting, Assistant Professor of Accounting, Undergraduate Program Director, College of Accounting (FACIC), Federal University of Uberlândia (UFU).

Silvia Pereira de Castro Casa Nova, Doctor in Accounting, Assistant Professor, Graduate Program Director, Department of Accountancy and Actuarial Science, College of Economics, Business and Accounting (FEA/USP), University of Sao Paulo (USP).

Edgard Bruno Cornacchione Junior, Ph.D., Professor and Chairman, Department of Accountancy and Actuarial Science, College of Economics, Business and Accounting (FEA/USP), University of Sao Paulo (USP).

Correspondence concerning this article should be addressed to Gilberto José Miranda, bloco 1F-219, Federal University of Uberlândia (Universidade Federal de Uberlândia), Av. João Naves de Ávila, 2121—Santa Mônica, Uberlândia, Minas Gerais, Brazil. E-mail: gilbertojm@facic.ufu.br. 
examines a specific point of this challenge, the impacts of the qualification of university professors on the performance of their students in the field of accounting in Brazil, based on the human capital theoretical framework.

According to human capital theory, education can be understood as investment associated with a determined return. This return can be evaluated from three perspectives: the individual, labor productivity, and society. This study focuses on the social perspective, with the subject of analysis being the reflections of the qualifications of teachers on the performance of their students.

There is a great deal of discussion in the international accounting literature about the relative qualification of teachers with academic qualification, holding $\mathrm{PhDs}$, and those with professional qualification, holding professional certifications such as certified public accountants (CPAs). At the center of this discussion is the relevance of academic qualification versus practical experience of accounting teachers, a theme that has attracted the attention of various researchers (Heijden, 2003; Annisette \& Kirkham, 2007; Harmer, 2009; Njoku, Heijden, \& Inanga, 2010; Marshall, Dombrowski, Garner, \& Smith 2010).

In Brazil, accounting education has undergone great transformations in recent years, due to: (1) the expansion of higher education system in general over the past two decades; (2) the increasing number of graduate degree programs in accounting; and (3) the changes in accounting itself, both nationally and internationally, in the former case because of the move toward convergence of Brazilian standards with International Financial Reporting Standards (IFRS).

Besides this unsettled scenario, accounting education in Brazil is marked by a relatively low average of academic credentials held by faculty members acting in undergraduate programs. Also, there are few studies targeting the quality of this teaching and few instruments for professional assessment. The Sufficiency Exam, established by the Federal Accounting Council (CFC) in 2011, revealed alarming results among practitioners. Of those taking the test throughout the country, only 30\% with bachelor's degrees in accounting and only $24 \%$ of the bookkeepers (classified as "accounting technicians", those with technical diplomas as opposed to college degrees) passed the test. On the teaching side, the Brazilian national examination for higher education students

(Exame Nacional de Desempenho de Estudantes-ENADE), only given to students of accounting degree programs twice so far, has shown poor results. In 2006, only $15.5 \%$ of the higher education institutions (HEIs) that were evaluated obtained scores of 4 or 5 (on a scale from 1 to 5). Likewise, in the 2009 evaluation, only $16.6 \%$ of the colleges and universities evaluated received these scores.

In this context, this study aims at investigating which variables of academic and professional qualification of accounting faculty in Brazil are related to the performance of students, as measured by the ENADE given in 2009.

\section{The Accounting Education Gap}

Sandroni (1999), in the field of economics, defines human capital as the result of "the set of investments aimed at the education and training of a determined population”. In this sense, Cattani and Holzmann (2006) define human capital theory from two connected standpoints. From the first standpoint, they refer to the individual strategies of each worker used in evaluation of the cost $x$ benefit related to the constitution of "personal capital". From the second standpoint, they refer to the training of workers through education, which is converted into higher productivity and hence greater gains for companies and workers.

In this line, according to Schultz (1973), investments in human development have a crucial influence on 
economic growth, with education being the basic investment in human capital and prerequisite for economic development, as well as for individual development, because by obtaining advanced education, people are "valorizing" themselves, in the same logic as they valorize capital. In other words, human capital has become one of the most important production factors, since educations is an essential economic factor for development. In this respect, various researchers have indicated the relevance of studies of the role of education in the economic development of a country (Hanushek, 2001; Hanushek \& Woessmann, 2008; Andrade, 2011).

The quality of education obviously depends on the quality of teachers. This quality can depend not only on the teachers' academic credentials, but also on their professional experiences in the field taught. This study focuses specifically on the impact of the qualification of teachers on the performance of their students in a specific area of business education, accounting. Accounting faculty members tend to have two profiles, those who are academically qualified (AQ) and those who are professionally qualified (PQ), with some overlap of those with certain levels of both types of qualification.

Njoku, Heijden, and Inanga (2010) state that after obtaining a degree, an accounting student can choose between pursuing an academic or a professional career, or both. Those choosing the academic route can obtain a master's degree and perhaps a doctorate in accounting, depending on their ambition and vocation, while those choosing the professional path can obtain certification of some type, varying across countries. According to Marshall et al. (2010, p. 9), such certification is "[...] a common link between accounting education and accounting practice”.

The Association to Advance Collegiate Schools of Business (AACSB) (AACSB, 2010b, p. 43) establishes in its assessment mechanisms that "Academic qualification requires a combination of original academic preparation (degree completion) augmented by subsequent activities that maintain or establish preparation for current teaching responsibilities”. In general, academic qualification is represented by a Ph.D. or equivalent degree, with initial and subsequent research related to the field taught. To be professionally qualified, a faculty member must have academic preparation, normally a master's degree in the area taught, plus relevant experience in that field. This professional experience should be relevant for the attributions assumed and significant in terms of the level of responsibility at the time of hiring (AACSB, 2010b). According to the AACSB, this professional experience is important because it assures that students will learn about current business practices and understand these practices' connection with research and theory (AACSB, 2010b).

The minimum percentages for academically qualified and professionally qualified faculty are established in the following form:

$$
\begin{aligned}
& \mathrm{AQ} /(\mathrm{PQ}+\mathrm{AQ}+\mathrm{O})>50 \% \\
& (\mathrm{AQ}+\mathrm{PQ}) /(\mathrm{AQ}+\mathrm{PQ}+\mathrm{O})>90 \%
\end{aligned}
$$

where:

$\mathrm{AQ}=$ Academically qualified;

$\mathrm{PQ}=$ Professionally qualified;

$\mathrm{O}=$ Others.

At least $50 \%$ of an institution's faculty should be academically qualified (for undergraduate courses) and $90 \%$ should have academic qualification or professional qualification. Nevertheless, there are some leeways to make strategic decisions on the distribution of $\mathrm{AQ}$ and $\mathrm{PQ}$ faculty according to discipline, program or location, consistent with the institution's mission and the needs of students (AACSB, 2010b).

In the evaluation criteria of the AACSB, the importance of an academic degree and research for the 
teaching of accounting is evident, on two counts. First, those with academic qualification (degree and research) should represent at least one-half of the faculty, while there is no minimum for professionally qualified faculty members. The only requirement is that those with professional and academic qualifications represent at least $90 \%$ of the faculty. In practice, academic qualifications in the institutions evaluated have on average represented twice those with professional qualifications (AACSB, 2010a). Second, for a teacher to be considered professionally qualified, he or she should have a master's degree and also have made intellectual contributions, so that there should be a "substantial cross-section of faculty in each discipline".

Njoku et al. (2010) indicate two conflicting challenges that affect accounting education. The first is that in the majority of countries, including Great Britain, United States, and Australia, the typical professional path is to become a practitioner rather than a teacher. However, academia is a strong preference of those with advanced degrees, such as PhDs in accounting. The reason for the preference is that the academic life emphasizes research. Therefore, qualified professionals, such as holders of credentials like Associate of the Institute of Chartered Accountants (ACA) and certified public accountants (CPAs), are not attracted to academic jobs. As a result, higher education institutions have a hard time hiring professors who are professionally qualified. The second challenge is that professionally qualified accountants have a strong preference for the market, because of the higher pay generally on offer. The consequence of this is a global shortage of academic accountants, notably in countries like Australia, where many universities demand simultaneous academic and professional qualification from their professors.

Marshall et al. (2010) conducted a survey about accounting teaching among 95 American accounting professors holding both a Ph.D. and CPA. The authors found that according to the respondents, there is no qualification that can replace experience in teaching and practice when one intends to become an effective accounting teacher. However, the study carried out by Behn et al. (2008) of the PhD programs listed in Hasselback's Accounting Faculty Directory 2006-2007 indicated that only 2\% of the respondent schools required any type of experience in the accounting profession when hiring professors.

In this respect, according to Njoku et al. (2010), while textbooks play an important role in conveying the required knowledge, there is also a need for practical examples to enhance learning. These practical examples bring the lessons alive and make a difference between teachers using the same book. Participating in a practical exercise provides rich learning experiences in the classroom and can lead to deeper academic discussions. Corroborating this position, Harmer (2009) states that a person who has never experienced the day-to-day routine of a company cannot know the many subtle ways an overall business activity is interconnected, and a large part of this complexity is overlooked by business degree programs.

Based on this, Njoku et al. (2010) argue that only academic training or professional experience alone is not enough to make a good accounting faculty. The authors suggest developing a professional called a "flexpert" (Heijden, 2003), that is, a professor who has not only the necessary skills to teach and do research, but also to perform activities in harmony with the practices in the accounting market. The AACSB (2010c), however, does not advocate that a single person should have two qualifications, but does take the position that both profiles - academic and professional qualification—are crucial for a higher education institution to attain high academic standards.

\section{Research Method}

According to M. D. Gall, J. P. Gall, and Borg (2007, p. 10), the objective of educational research is to 
generate knowledge that describes, makes predictions, allows improvements and explains educational processes and practices. In this study, descriptive strategy was used to tackle the research question. According to those authors, this involves description of natural or social phenomena regarding their form, structure, activity, changes over time and relations with other phenomena, among others (M. D. Gall, J. P. Gall, \& Borg, 2007).

Further according those authors, this type of research depends strongly on the measurement and observation instruments, besides description of the characteristics of the target population or phenomenon. The main aim is to establish relationships between variables and facts. For this purpose, the questionnaires were used to gather primary data. These questionnaires were sent to the managers (e.g., coordinators, deans, department heads, and directors) of 902 college-level accounting programs receiving scores from ENADE in 2009.

The questionnaire was structured in the following blocks of questions: (1) data on the institution and the respondent; (2) factors involved in academic and professional qualification; and (3) open reflections (an open space where the respondents could record other information deemed relevant regarding the qualification of the faculty members of their respective institutions). The factors involved in academic and professional qualifications (block 2) were based on the Delphi technique. The panel of experts included the participation of 21 Brazilian, American, and British participants in the areas of accounting, business administration, and education. They were representatives of academia, such as professors in doctoral programs, researchers, and educational managers (National Association of Graduate Education and Research in Administration-ANPAD, National Association of Graduate Accounting Programs-ANPCONT, and the Coordination for the Improvement of Higher Education Personnel-CAPES of the Brazilian Ministry of Education) and the market, such as professionals and representatives of their organizations and government regulators (AICPA, ISAR, AACSB, Brazilian Securities Commission—CVM, and the Federal Accounting Council—CFC).

Two trial runs were carried out to determine the quality of the questionnaire. The final questionnaire was applied in two steps: (1) in person during the Sixth Meeting of Brazilian Accounting Program Coordinators, held from August 4-6, 2011, in Fortaleza, Ceará; and (2) electronically, hosted by the Google platform. The population under study was the accounting degree programs evaluated by the ENADE in 2009 (902 HEIs). The final sample consisted of 218 HEIs, 24.2\% of those evaluated by the ENADE in 2009.

\section{Results and Discussion}

Since the questionnaires were addressed to managers of HEIs in general, rather than to a specific person or position, the respondents were classified by position, with the following breakdown: $72.9 \%$ of the respondents were coordinators of the institution, $15.6 \%$ were department heads or directors (including one dean and one general secretary), and $11.5 \%$ were professors.

Table 1 contains a summary of the sample distribution by the country's five official geographic regions. In absolute terms, the Southeast and South, respectively, provided the largest numbers of responses, and the South was also the highest in percentage terms (27.9\% of that region's institutions participated in the survey). The lowest participation came from the North, with $22.8 \%$ of the institutions.

Of the responding HEIs, $20.2 \%$ were public institutions (34.9\% of public HEIs in the country offering accounting programs). The other $79.8 \%$ were private institutions $(22.4 \%$ of the nationwide total with accounting programs). Nearly half of the responding institutions (49.1\%) were classified as colleges, representing $20.5 \%$ of the country's colleges with accounting programs. The HEIs established in the form of 
universities made up $35.3 \%$ of the sample and $27.8 \%$ of the country's universities with accounting programs. Finally, university centers represented $15.6 \%$ of the sample and $33.7 \%$ of the HEIs with this type of academic organization that offer accounting degrees.

Table 1

Sample by Geographic Region: Accounting Degree Programs in Brazil

\begin{tabular}{lccccc}
\hline Region & \multicolumn{2}{c}{ Number of Responding IHEs } & Number Nationwide & Sample \% \\
\hline Southeast & 83 & $38.1 \%$ & 362 & $40.1 \%$ & $22.9 \%$ \\
South & 55 & $25.2 \%$ & 197 & $21.9 \%$ & $27.9 \%$ \\
Northeast & 38 & $17.4 \%$ & 167 & $18.5 \%$ & $22.8 \%$ \\
Midwest & 26 & $11.9 \%$ & 110 & $12.2 \%$ & $23.6 \%$ \\
North & 16 & $7.4 \%$ & 66 & $7.3 \%$ & $24.2 \%$ \\
\hline Total & 218 & $100 \%$ & 902 & $100 \%$ & \\
\hline
\end{tabular}

Note. The institutions with units in more than one state were only considered in the state of origin.

\section{Faculty Qualifications}

Table 2 contains items regarding qualification of the faculty members of the investigated HEIs. The respondents were asked to report the number of faculty members teaching courses with accounting content for the program in 2011. Then they were asked to report the number of faculty members with the attributes shown in Table 2. By dividing the number of faculty members relative to each of the investigated items by the total number teaching courses in the year, the percentages of the faculty of each HEI having each of the attributes of interest were obtained.

As can be observed, the items with the lowest positive response rates were those regarding publications (182 positive responses for publications in top-quality journals—with Qualis ratings of B2 or above, and 178 for other periodicals). This result was expected, because information about publications is specific to each faculty member, so it is natural that some coordinators, directors or department heads would not have full information in this respect. Another point that stands out is the low "Proportion of faculty with PhDs", of only 7\% of the HEIs investigated, consisting of $267 \mathrm{PhDs}$ from 218 institutions surveyed. This situation results from the late development of graduate accounting programs in Brazil, as mentioned before. For a long while there was only one program awarding doctoral degrees in accounting in Brazil, the Graduate Program in Control and Accounting offered by the College of Economics, Business and Accounting (FEA/USP) at the University of São Paulo. It was only in 2008 that CAPES authorized the second such program, and at present there are only four in the country.

As for the number of $\mathrm{PhD}$ holders, the number of faculty members with publications was also low. On average, only $14 \%$ of the faculty of the investigated HEIs had a member with articles published in international journals or domestic ones with top-ranked Qualis/CAPES ratings (e.g., A1, A2, B1, or B2), and 24\% had publications in other periodicals. Similarly, the participation in research groups was low, at only $21 \%$.

In contrast, the percentages regarding professional qualification attributes were higher in nearly all cases, notably those related to professional experience, which were above $50 \%$, except for international credentials (1\%) and accreditation for independent auditing from the CVM (5\%).

Table 3 (presented partially) shows the correlations between the variables investigated and the result of the ENADE. 
Table 2

Faculty Qualification Items of the IHEs: Accounting Courses in Brazil Evaluated by the 2009 ENADE

\begin{tabular}{|c|c|c|c|}
\hline Variables & No. & Mean & Std. Dev. \\
\hline (1) Proportion of faculty with PhDs & 218 & $7 \%$ & $13 \%$ \\
\hline (2) Proportion of faculty with MScs & 218 & $44 \%$ & $25 \%$ \\
\hline (3) Proportion of full-time faculty & 218 & $50 \%$ & $34 \%$ \\
\hline $\begin{array}{l}\text { (4) Proportion of faculty with publications in international scientific periodicals or } \\
\text { Qualis/CAPES ratings }=\mathrm{A} 1, \mathrm{~A} 2, \mathrm{~B} 1 \text {, or B2 }\end{array}$ & 182 & $14 \%$ & $23 \%$ \\
\hline $\begin{array}{l}\text { (5) Proportion of faculty with publications in periodicals with Qualis ratings of B3 or lower, or } \\
\text { not classified in Qualis }\end{array}$ & 178 & $24 \%$ & $27 \%$ \\
\hline (6) Proportion of faculty participating in research groups & 203 & $21 \%$ & $21 \%$ \\
\hline (7) Proportion of faculty regularly participating in academic events in the accounting area & 213 & $34 \%$ & $28 \%$ \\
\hline $\begin{array}{l}\text { (8) Proportion of faculty who are members of research associations or entities, such as ANPAD, } \\
\text { ANPCONT, and CAPES }\end{array}$ & 215 & $7 \%$ & $13 \%$ \\
\hline (9) Proportion of faculty with applied research projects in the accounting area (academia/market) & 218 & $19 \%$ & $20 \%$ \\
\hline (10) Proportion of faculty regularly participating in professional events in the accounting area & 214 & $47 \%$ & $30 \%$ \\
\hline $\begin{array}{l}\text { (11) Proportion of faculty with at least two years of professional practice in the accounting area, } \\
\text { except in academia }\end{array}$ & 215 & $74 \%$ & $28 \%$ \\
\hline $\begin{array}{l}\text { (12) Proportion of faculty with experience as consultants, advisers or technical opinion writers in } \\
\text { the accounting area }\end{array}$ & 216 & $54 \%$ & $29 \%$ \\
\hline (13) Proportion of faculty with experience in business management/administration & 214 & $52 \%$ & $28 \%$ \\
\hline (14) Proportion of faculty with professional accounting certification (CRC) & 208 & $76 \%$ & $26 \%$ \\
\hline $\begin{array}{l}\text { (15) Proportion of faculty with certification as independent auditors by the Brazilian Securities } \\
\text { Commission (CVM) } \\
\text { (16) Proportion of faculty with international professional certifications, such as Certified Public }\end{array}$ & 218 & $5 \%$ & $8 \%$ \\
\hline $\begin{array}{l}\text { Accountants (CPA), Certified Management Accountants (CMA), or Association of Chartered } \\
\text { Certified Accountants (ACCA) }\end{array}$ & 217 & $1 \%$ & $3 \%$ \\
\hline (17) Proportion of faculty with extension projects involving academia and the community & 215 & $15 \%$ & $16 \%$ \\
\hline
\end{tabular}

All the variables related to academic degrees and research had positive and significant correlation with the result of the ENADE evaluation. The variable "Scientific events" was significant at 5\%, while all the others were significant at $1 \%$, as shown in Table 3.

The variables related to participation at professional events, professional experience, and professional credentials did not present significant positive correlations with student performance (ENADE variable). These results are in harmony with human capital theory, that is, the higher the academic degree, the more published works a person will tend to have, with reflections on teaching performance.

In this respect, Bell, Frecka, and Solomon (1993, p. 47) state that “[...] consistent with other fields, there is a positive, statistically reliable association between accounting teaching effectiveness and research productivity”. Likewise, Collier (1998) cited by Njoku et al. (2010), also states there is a strong relationship between high-quality teaching and relevant research efforts. Annisette and Kirkham (2007, p. 10), in turn, argue that "where the research-practice link is non-existent or weak (as in the case of accountancy), the university is of little use to a profession as a means of diffusing, expanding and developing professionally relevant knowledge”. 
Table 3

Correlations: Qualifications of Teachers and ENADE Results

\begin{tabular}{|c|c|c|c|c|}
\hline Variables & Test & $n$ & Correlation Coefficient & $p$-value \\
\hline ENADE & Pearson's correlation & 171 & 1 & \\
\hline (1) $\mathrm{PhDs}$ & Spearman's correlation & 171 & $0.267^{* *}$ & 0 \\
\hline (2)MScs & Pearson’s correlation & 171 & $0.452^{* *}$ & 0 \\
\hline (3) Full-Time Professors & Pearson's correlation & 171 & $0.411^{* *}$ & 0 \\
\hline (4) Publications $\geq$ B2 & Spearman's correlation & 140 & $0.270^{* *}$ & 0.001 \\
\hline (5) Publications < B2 & Spearman's correlation & 137 & $0.339^{* *}$ & 0 \\
\hline (6) Research Groups & Spearman's correlation & 163 & $0.265^{* *}$ & 0.001 \\
\hline (7) Scientific Events & Spearman's correlation & 167 & $0.189^{*}$ & 0.014 \\
\hline (8) Research Associations & Spearman's correlation & 169 & $0.327^{* *}$ & 0 \\
\hline (9) Applied Research & Spearman's correlation & 171 & $0.347^{* *}$ & 0 \\
\hline (10) Professional Events & Pearson’s correlation & 168 & 0.055 & 0.479 \\
\hline (11) Professional Experience & Spearman's correlation & 169 & 0.032 & 0.678 \\
\hline (12) Consulting Experience & Spearman's correlation & 170 & 0.111 & 0.148 \\
\hline (13) Management Experience & Pearson’s correlation & 167 & -0.069 & 0.375 \\
\hline (14) CRC Registration & Spearman's correlation & 161 & 0.082 & 0.298 \\
\hline (15) CVM Registration & Spearman's correlation & 171 & 0.018 & 0.82 \\
\hline (16) CPA/CMA/ACCA & Spearman's correlation & 170 & 0.15 & 0.052 \\
\hline (17) Extension Projects & Spearman's correlation & 170 & $0.178^{*}$ & 0.021 \\
\hline
\end{tabular}

Notes. ${ }^{* *}$ Correlation significant at $1 \%$; ${ }^{*}$ Correlation significant at $5 \%$.

\section{Conclusions}

Accounting has undergone great changes in recent years, both in Brazil and internationally. These changes require highly trained professionals able to work effectively in the context of globalization of accountancy. However, nationwide evaluation methods in Brazil (ENADE assessment of graduating accounting majors) indicate low performance of accounting education.

As is obvious, the protagonists in the teaching and learning process are instructors and students. In this respect, qualified teachers should significantly contribute to student performance. But the qualification of accounting faculty is a complex subject and is difficult to measure. Researchers in the accounting area, both inside and outside Brazil, heatedly discuss the relative importance of academic versus professional qualification. Therefore, the aim of this study was to investigate which variables related to the academic and professional qualifications of faculty members in accounting programs in Brazil are related to student performance, as measured by the ENADE (2009).

It was found that the percentage of faculty members holding doctoral degrees in accounting and active in accounting programs is low, at only 7\%, and the number of people with $\mathrm{PhDs}$ in other areas teaching in these programs is actually higher. Furthermore, 14\% of the faculties of the investigated HEIs have professors with publications in international scientific journals or top-ranked national ones (with Qualis/CAPES ratings of A1, A2, B1 or B2). With respect to publications in other periodicals, this percentage rises to $24 \%$. It was also found that only $1 \%$ of faculty members at the investigated HEIs have international credentials and $5 \%$ have credentials to act as independent auditors granted by the Brazilian Securities Commission (CVM).

In correlating the variables related to the academic and professional qualification of faculty members in Brazilian accounting programs with the results of the ENADE (2009), it was found that all the variables related 
to advanced degrees and research activities have a positive and significant correlation, although these variables have low figures among the investigated HEIs. In contrast, the variables related to professional events, professional experience, and professional credentials, which higher rates among the HEIs, are not significantly positively correlated with the student performance variable.

These results are coherent with human capital theory and also the assessment criteria, both of CAPES in Brazil (which puts greatest weight on holding advanced degrees and research activities, mainly in quantitative form) and of the AACSB (which although employing qualitative criteria, also gives substantially higher weight to degrees and research: academic qualification).

These findings naturally lead to reflection on the causes of the low academic qualification in accounting programs in Brazil (the average percentage of PhDs in the investigated HEIs is only 7\%, and the majority of them hold degrees in other disciplines). Despite the substantial growth in the number of graduate programs in recent years, there is still much to be done, because only 19 institutions offer master's programs in accountancy and only four offer doctoral programs authorized by CAPES. In Brazil only slightly over $200 \mathrm{PhDs}$ in accounting have been granted (an average of about $0.2 \mathrm{PhD}$ holders in Accounting per institution: only 200 people for 1,000 HEIs). While in the United States there were more than $200 \mathrm{PhDs}$ by the end of 1960s.

In this sense, it is necessary for CAPES to strengthen its policies to support expansion of graduate accounting programs, and for the Brazilian Ministry of Education also to establish programs to qualify faculty members of HEIs offering accounting programs, mainly private ones, which have the lowest level of professors with advanced degrees. Finally, teaching institutions in Brazil should seek out international partnerships with institutions offering strong $\mathrm{PhD}$ programs as a way of boosting the quality and quantity of accounting $\mathrm{PhD}$ holders in Brazil. Based on the strong Brazilian economic outlook, the federal government (e.g., Ministry of Education and Ministry of Science and Technology) is offering interesting grants to support establishing international cooperation in this line (i.e., two institutions, one Brazilian and one from abroad, could partner aiming at offering a quality advanced degree program).

Holding an advanced degree is important, and when the proportion of faculty with advanced degrees is low, the publications (mainly the relevant ones) also tend to be low. This is reflected in the findings, whereby the average percentage of professors with publications in Brazilian periodicals with Qualis rating above B2 or in international publications was only $14 \%$. This means that it is important to increase the number of faculty members holding $\mathrm{PhDs}$, as already discussed, and equally important to stimulate relevant research. An increase in the percentage of professors holding advanced degrees does not necessarily increase the publication rate (Cunha, 2007).

It must be pointed out that accounting education in Brazil has some peculiarities when compared with other countries, such as the United States. The predominant assessment mechanisms in the United States are specific for the area of business (AACSB), so they include qualifications that are exclusive to the area (professional qualification). In Brazil, these mechanisms come from the public sphere and are applicable to higher education in general, not distinguishing among specific aspects of the profession, and thus they essentially value academic qualification. As a result of not assessing professional qualification attributes, there is no stimulus to improve these attributes, such as a professional credential like a CPA. It is expected that with the implementation of the Sufficiency Exam in 2011, the Brazilian professional credential (CRC) can in the future achieve a status that is more equivalent to the CPA. Paradoxically, it was also found that although the national educational quality assessments place emphasis on faculty holding advanced degrees, the levels of 
faculty members with such degrees in accounting are very low in Brazil, unlike the case of the United States.

Furthermore, outside Brazil (specifically the United States and United Kingdom) there are other factors strengthening professional qualification, namely: (1) strong professional credentials (CPA, CMA, ACCA), requiring courses lasting at least 150 hours besides a proficiency exam (an area where Brazil is making progress, but is still has far to go); and (2) minimum of a master's degree, complemented by subsequent research in the area of teaching. In Brazil, because of the low number of faculty with advanced degrees, the holding of a master's degree was considered to be an academic qualification attribute rather than a professional one (as recommended by the AACSB). Therefore, due to the specific Brazilian scenario, professional qualification (in the framework) was restricted almost exclusively to technical activity.

In this sense, as happens in other countries in the field of accounting (and in other areas such as medicine), professional qualification should be closer to academic qualification. The area must overcome the so-called gap between theory and practice for the area as a whole to progress at faster speeds. In order to improve professional qualification, it is necessary, among other aspects, to invest in advanced degree programs and research efforts. Indeed, CAPES in Brazil has been working to strengthen professional qualification of accountants, such as by stimulating the creation of graduate accounting degree programs.

The changes that affect the profession, as Brazilian accounting standards converge to international standards, as well as technological advances are also changing accounting education. As things stand now, professional qualification sets priority on mastery of technical knowledge rather than elements that in the near future will be required: critical reasoning, communication skills, ability to make judgments, to mention a few. Structured or semi-structured (technical) problems are increasingly being handled by machines because of technological advances. Chances are that an instructor having exclusively technical qualification will not be prepared to help students, in the classroom, to attain the competencies demanded in this "new market". Therefore, the way to change this scenario over the long term is for HEIs to invest in better academic qualification.

\section{Implications for HRD}

One of the main challenges of emerging nations is to develop highly trained human resources (Hanushek, 2001; Hanushek \& Woessmann, 2008; Andrade, 2011). In the case of Brazil, substantial investments have been made in graduate education, due to its potential to produce professors to teach at institutions of higher education and to promote the qualification of professionals in various areas (Miranda, 2011; Cunha, 2007). Hence, in focusing on the qualifications of teachers that affect the performance of their students, this paper contributes to reflection on the results of this policy of investment in the academic preparation of teachers and provides information on the possibilities of their improvement. The results provide evidence of a high positive correlation between academic qualification of teachers, related to holding master's and doctoral degrees and active research efforts, and the performance of students (Raj, Friedman, \& Rockoff, 2011; Miranda, 2011). Similar studies in other academic areas that are strategic for Brazil, such as engineering (or more generally the STEM field), can help to improve educational policies, drawing on the experience of countries whose higher education systems, due to their stage of development, and are already consolidated. Hence, possibilities for partnerships between institutions in developing countries with their counterparts in developed countries can be envisioned. With respect to groups of developing countries, with special emphasis on the so-called BRICs, due 
to shared stage of economic development and the inherent challenges, this study provides possibilities for reflection on successful experiences in the area of education and formation of human capital. This exchange of experiences is important to strengthen the development of human resources in all countries. Such exchange can be particularly beneficial for African countries that share cultural and linguistic roots with Brazil, allowing them to emulate what has been successful in Brazil.

Because of the broad and complex nature of this theme, further studies are necessary. Among them it can be suggested: (1) investigation of whether there are associations between academic and professional qualifications and the results of the exams for professional licenses (e.g., CPA in the USA and CFC Sufficiency Exam in Brazil); (2) investigation of the academic and professional qualifications of accounting courses, but at the individual level in order to obtain a more accurate scale to measure the qualification of faculty members; and (3) empirical investigation of whether the ENADE in Brazil can indicate the competency of students to carry out advanced studies.

\section{References}

AACSB. (2010a). Data and research. Retrieved August 20, 2010, from http://www.aacsb.edu/dataandresearch/reports/default.asp AACSB. (2010b). Accreditation: Eligibility procedures and accreditation standards for business accreditation. Retrieved August 20, 2010, from http://www.aacsb.edu/accreditation/process/initial.asp

AACSB. (2010c). AQ/PQ status: Establishing criteria for attainment and maintenance of faculty qualifications-An interpretation of AACSB standards. Retrieved August 24, 2010, from http:/www.aacsb.edu/publications/papers/

Andrade, E. C. (2011). Rankings em Educação: Tipos, Problemas, Informações e Mudanças: Análise dos Principais Rankings Oficiais Brasileiros (Rankings in Education: types, problems, information and changes-An analysis of main official rankings). Estudos Econômicos, 41(2), 323-343.

Annisette, M., \& Kirkham, L. M. (2007). The advantages of separateness explaining the unusual profession-university link in English Chartered Accountancy. Critical Perspectives on Accounting, 18, 1-30.

Ardichvili, A., Jondle, D., Kowske, B., Cornachione, E., Li, J., \& Thakadipuram, T. (2012). Ethical cultures in large business organizations in Brazil, Russia, India, and China. Journal of Business Ethics, 105, 415-428.

Behn, B. K., Carnes, G. A., Krull, G. W., Jr. Stocks, K. D., \& Reckers, P. M. J. (2008). Accounting doctoral education-2007: A report of the joint AAA/APLG/FSA doctoral education committee. Issues in Accounting Education, 23(3), 357-367.

Bell, T. B., Frecka, T. J., \& Solomon, I. (1993). The relation between research productivity and teaching effectiveness: Empirical evidence of accounting educators. Accounting Horizons, 7(4), 33-47.

Cattani, A. D., \& Holzmann, L. (2006). Dicionário de Trabalho e Tecnologia (Dictionary of work and technology) (vol. 1). Porto Alegre: Ed. UFRGS.

Cunha, J. V. A. (2007). Doutores em Ciências Contábeis da FEA/USP: análise sob a óptica da teoria do capital humano (Accounting PhD graduates from FEA/USP: Analisys in light of human capital theory). Tese de doutorado em Ciências Contábeis, Programa de Pós-Graduação em Ciências Contábeis, Departamento de Contabilidade e Atuária, FEA/USP, São Paulo, Brasil.

Gall, M. D., Gall, J. P., \& Borg, W. R. (2007). Educational research: An introduction (8th ed.). Boston: Pearson Allyn \& Bacon.

Hanushek, E. A. (2001). International encyclopedia of the social \& behavioral sciences (pp. 4200-4208). In P. Baltes, B., Smelser, \& J. Neil (Ed.). Amsterdam: Elsevier Science.

Hanushek, E., \& Woessmann, L. (2008). The role of cognitive skills in economic development. Journal of Economic Literature, 46(3), 607-668.

Harmer, B. M. (2009). Teaching in a contextual vacuum: Lack of prior workplace knowledge as a barrier to sense making in the learning and teaching of business courses. Innovations in Education and Teaching International, 46(1), 41-50.

Heijden, B. I. J. M. (2003). Organizational influences upon the development of occupational expertise throughout the career. International Journal of Training \& Development, 7(3), 142-165.

Marshall, P. D., Dombrowski, R., Garner, M., \& Smith, K. (2010). The Accounting Education Gap. The CPA Journal, 80(6), 6-10. 
Miranda, G. J. (2011). Relações entre as qualificações do professor e o desempenho discente nos cursos de graduação em Contabilidade no Brasil (Relations between the faculty qualifications and the student's performance in Brazilian undergraduate programs in accountancy). Tese de doutorado em Ciências Contábeis, Programa de Pós-Graduação em Ciências Contábeis, Departamento de Contabilidade e Atuária, FEA/USP, São Paulo, Brasil.

Njoku, J. C., Heijden, B. I. J. M., \& Inanga, E. L. (2010). Fusion of expertise among accounting faculty: Towards an expertise model for academia in accounting. Critical Perspectives on Accounting, 21(1), 51-62.

Raj, C., Friedman, J. N., \& Rockoff, J. (2011). The long-term impacts of teachers: Teacher value-added and student outcomes in adulthood. Executive Summary of National Bureau of Economic Research, Harvard University.

Sandroni, P. (1999). Novíssimo dicionário de economia (New dictionary of economy). São Paulo: Best Seller.

Schultz, T. (1973). O capital humano (The human capital). Rio de Janeiro: Zahar. 